\title{
Pemanfaatan dan Sosialisasi Video Pembelajaran Berbasis Sparkol Videoscribe Pada Materi Matriks Sebagai Sumber Belajar Bagi Siswa dan Sebagai Inovasi Pembelajaran Bagi Guru Kelas XI SMA/SMK di Jorong Kampung Padang Paraman Dareh, Nagari Aia Manggih, Kecamatan Lubuk Sikaping, Kabupaten Pasaman, Provinsi Sumatera Barat dengan Metode SYIFW (Sharing to Youtube, Instagram, Facebook, dan WhatsApp)
}

\author{
Lialy Sarti, Jurusan Matematika, Universitas Negeri Padang
}

\begin{abstract}
Pengantar
Pemanfaatan dan sosialisasi video pembelajaran merupakan solusi efektif untuk pembelajaran online di tengah pandemi Covid-19. Video pembelajaran ini berbantuan aplikasi Sparkol Videoscribe. Kegiatan ini bertujuan untuk membantu siswa belajar di tengah pandemi Covid-19. Selain itu, juga memberikan inovasi bagi guru dalam mengembangkan media pembelajaran online. Metode yang digunakan adalah SYIFW (Sharing to Youtube, Instagram, Facebook, and WhatsApp). Kegiatan ini dilaksanakan di Jorong Kampung Padang Paraman Dareh, Nagari Aia Manggih, Kecamatan Lubuk Sikaping, Kabupaten Pasaman, Provinsi Sumatera Barat. Kegiatan ini melibatkan siswa SMA/SMK kelas XI. Hasil survei menunjukkan bahwa dengan menggunakan video pembelajaran berbasis Sparkol Videoscribe, 17 dari 20 siswa bisa memahami pelajaran dengan baik. Dengan video pembelajaran, siswa juga bersemangat untuk belajar. Selain itu, belajar juga menjadi menyenangkan karena ada animasi atau gambar yang menarik. Sehingga, video pembelajaran dapat mengatasi kesulitan siswa dalam belajar online di tengah pandemi Covid-19. Selain itu, salah satu guru matematika juga terinovasi menggunakan video pembelajaran berbasis Sparkol Videoscribe sebagai media pembelajaran. Video pembelajaran tersebut dapat membantu guru menyampaikan pelajaran. Video pembelajaran dapat memberikan penjelasan materi pelajaran secara jelas dan rinci. Sehingga, siswa dapat lebih mudah memahami pelajaran dengan adanya penjelasan dari guru. Dengan demikian, dapat disimpulkan bahwa video pembelajaran berbasis Sparkol Videoscribe dapat dijadikan sebagai sumber belajar bagi siswa dan sebagai inovasi pembelajaran bagi guru.
\end{abstract}

\section{Pendahuluan}

Pemanfaatan dan sosialisasi video pembelajaran merupakan solusi efektif untuk pembelajaran online di tengah pandemi Covid-19. Video pembelajaran ini menggunakan aplikasi Sparkol Videoscribe. Video pembelajaran merupakan media pembelajaran audio visual. Video pembelajaran dapat dijadikan sebagai 
sumber belajar bagi siswa. Sehingga, dapat membantu siswa mengatasi kesulitan dalam belajar. Selain itu, video pembelajaran juga dapat membantu guru dalam membuat media pembelajaran yang kreatif. Namun, video pembelajaran masih belum dimanfaatkan dalam pembelajaran di Sumatera Barat, terkhususnya di Jorong Kampung Padang Paraman Dareh, Nagari Aia Manggih.

Berdasarkan hasil survei, masih banyak siswa yang mengalami kesulitan dalam belajar. Survei dilakukan terhadap 20 orang siswa kelas XI SMA/SMK melalui angket secara online. Dari 20 orang siswa tersebut, 19 orang mengalami kesulitan saat belajar online (daring). Beberapa faktor yang menyebabkan siswa kesulitan dalam belajar adalah (1) tidak adanya penjelasan materi dari guru sehingga siswa harus belajar sendiri; (2) kurangnya minat belajar karena belajar menjadi membosankan; (3) tidak ada yang bisa ditanyai jika ada pelajaran yang tidak dipahami; dan (4) tidak ada kuota internet untuk mencari informasi/pelajaran. Oleh karena itu, dengan kesulitan yang dihadapi, siswa menjadi malas belajar.

Sumber belajar yang digunakan oleh siswa juga belum terfasilitasi. Berikut hasil survei tentang sumber belajar yang digunakan siswa saat belajar di rumah.

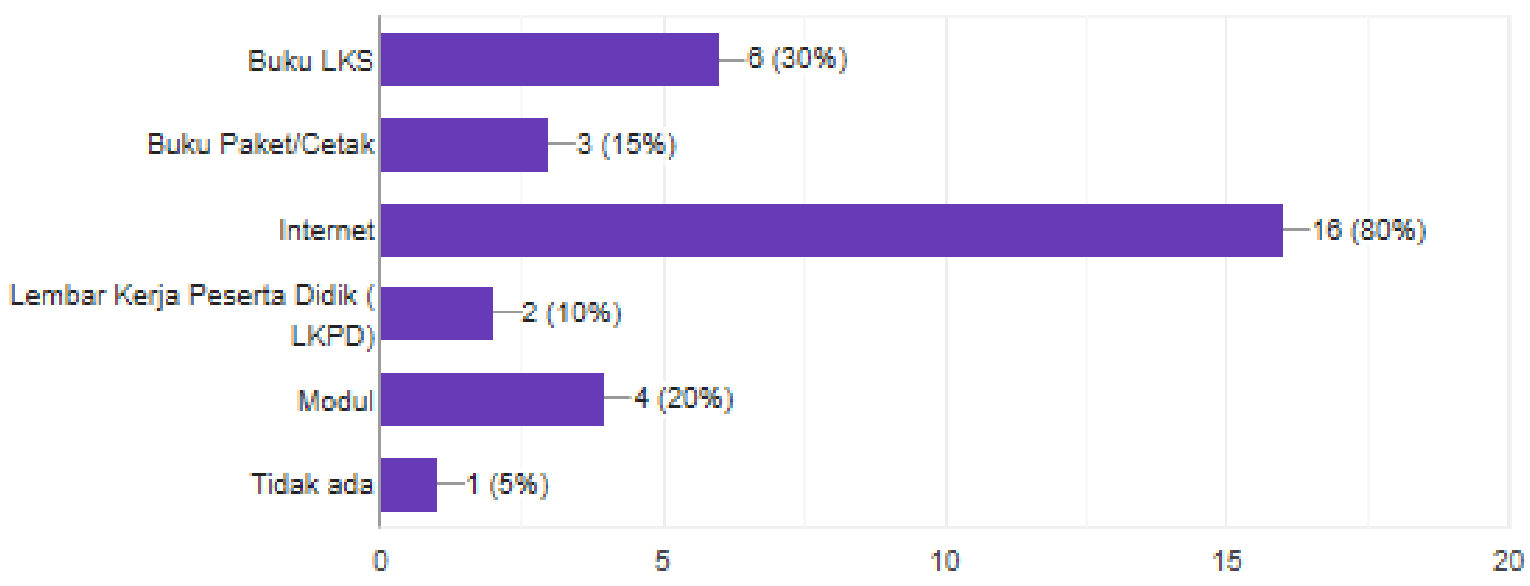

\section{Gambar 1. Sumber Belajar yang Digunakan Siswa}

Dari diagram tersebut, dapat dilihat bahwa kebanyakan siswa hanya mengandalkan internet dalam mencari informasi/pelajaran. Sedangkan, sangat sedikit siswa yang menggunakan buku, Lembar Kerja Peserta Didik (LKPD), dan modul sebagai sumber belajar. Sehingga, dapat dikatakan sumber belajar siswa masih terbatas. Oleh karena itu, siswa mengalami kesulitan dalam memahami pelajaran maupun mengerjakan tugas.

Kemudian, dengan sumber belajar yang digunakan tersebut, hanya 55\% siswa yang mampu memahami pelajaran dengan baik. 


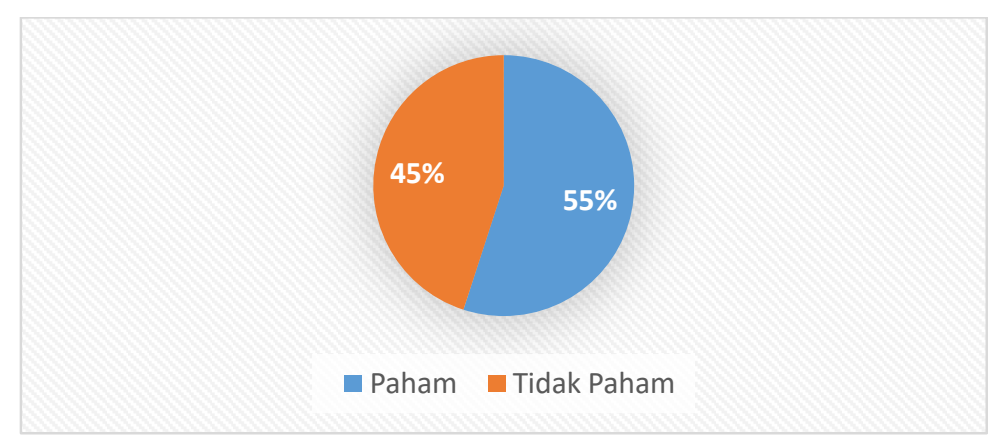

\section{Gambar 2. Persentase Tingkat Kepahaman Siswa Terhadap Pelajaran}

Selain itu, berdasarkan wawancara dari salah satu guru matematika, hanya sebagian kecil siswa yang memahami pelajaran. Bahkan, hanya 4-6 siswa yang paham dalam satu kelas yang berjumlah 35 orang. Guru tersebut juga merasakan kesulitan dalam mengajar di tengah pembelajaran online saat ini. Guru pun juga merasakan metode atau media yang digunakannya dalam mengajar masih belum efektif. Guru hanya memberikan ringkasan materi pelajaran secara detail melalui WhatsApp. Selain itu, guru juga memberika voice note berisi penjelasan materi pelajaran.

Berdasarkan latar belakang di atas, maka dilaksanakan program kerja KKN. Proker ini bertujuan untuk mensosialisasikan video pembelajaran berbasis Sparkol Videoscribe sebagai (1) sumber belajar bagi siswa; dan (2) inovasi media pembelajaran bagi guru. Sehinggga, diharapkan dengan Proker KKN ini, dapat membantu siswa dalam memahami pelajaran. Selain itu, juga diharapkan dapat membantu guru dalam mengembangkan media pembelajaran yang kreatif dan efektif.

Strategi pencapaian proker ini dilakukan melalui tiga tahapan, sebagaimana tergambar pada Gambar 1. Tahapan pertama adalah persiapan, dimulai dengan perizinan KKN dan survei situasi di lapangan. Survei dilakukan terhadap siswa kelas XI SMA/SMK melalui angket secara online (google form). Angket ini bertujuan untuk melihat kendala/kesulitan siswa dalam belajar. Angket tersebut kemudian dikirim melalui kontak WhatsApp siswa. Selain itu, pada tahapan ini juga dilakukan wawancara terhadap guru melalui WhatsApp. Sehingga, pada tahapan ini semua informasi tentang target sudah ditelusuri. Selain itu, perencanaan tentang program yang akan dilaksanakan juga sudah dirancang. Perencanaan dimulai dengan pembuatan video pembelajaran berbantuan aplikasi Sparkol Videoscribe. Video pembelajaran yang dibuat tentang materi matriks. Materi tersebut merupakan pelajaran kelas XI SMA/SMK semester 1. Materi matriks terdiri dari 2 Kompetensi Dasar (KD). Sehingga, ditahapan ini akan dibuat video pembelajaran sesuai $\mathrm{KD}$ tersebut. 

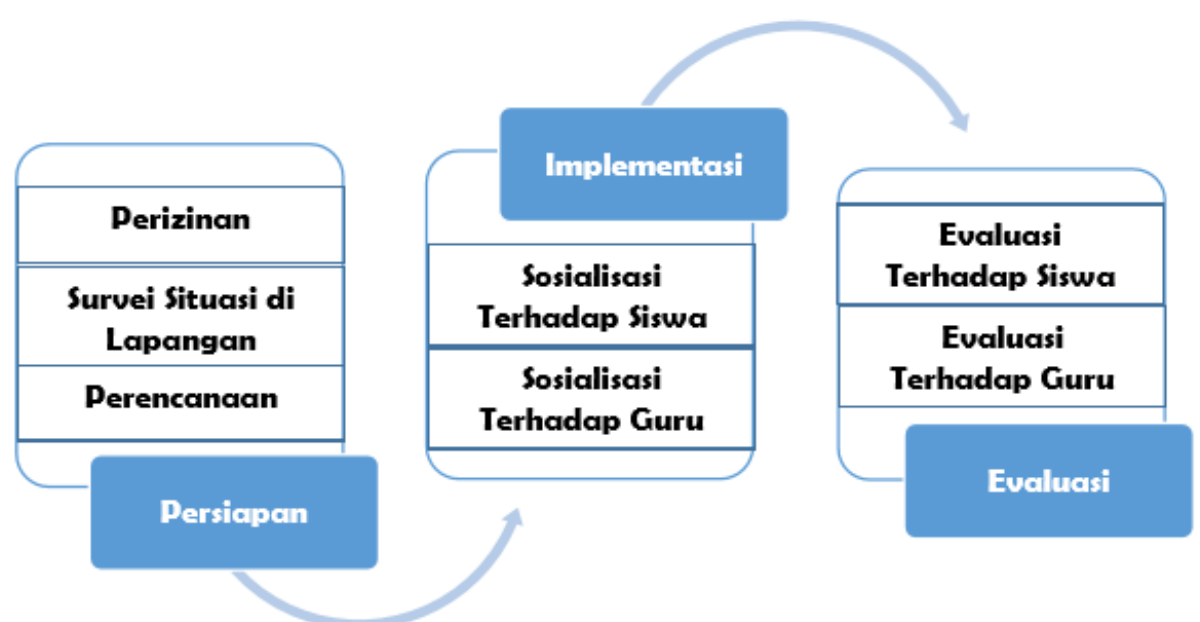

Gambar 3. Strategi Pemecahan Masalah

Tahapan kedua merupakan implementasi program kerja yang sudah direncanakan. Pemanfaatan video pembelajaran sebagai sumber belajar siswa dilakukan dengan mengirimkan video yang telah dibuat. Video tersebut dipublikasikan dengan metode SYIFW (Sharing to Youtube, Instagram, Facebook, and WhatsApp). Metode ini adalah metode untuk mempublikasikan video melalui jejaring sosial Youtube, Instagram, Facebook, dan Whatsapp. Video tersebut dikirimkan kepada 20 orang siswa melalui WhatsApp, serta di-upload di Youtube, Facebook, dan Instagram. Sedangkan, sosialisasi video pembelajaran ini kepada guru dilakukan secara langsung dengan mendatangi rumah guru.

Tahapan akhir adalah mengevaluasi proker yang sudah diimplementasikan. Tahapan ini dilakukan melalui angket secara online (google form). Angket ini bertujan untuk mengetahui tanggapan siswa dalam menggunakan video pembelajaran sebagai sumber belajar. Sehingga dapat diketahui, video pembelajaran dapat mengatasi kesulitan belajar atau tidak. Angket ini diberikan kepada siswa melalui grup WhatsApp yang terdiri dari 20 siswa. Selain itu, angket juga diberikan secara langsung dengan mendatangi rumah siswa. Pada tahapan ini, juga akan dilakukan wawancara terhadap guru secara langsung dengan mendatangi rumah guru. Tujuannya adalah untuk mengetahui tanggapan guru terhadap video pembelajaran. Sehingga dapat diketahui, apakah video pembelajaran dapat dijadikan inovasi pembelajaran bagi guru atau tidak.

\section{Implementasi}

\section{Kajian Strategis}

Sosialisasi merupakan suatu proses penyampaian pembelajaran, pengetahuan, nilai, dan norma untuk dipahami oleh masyarakat $(1,17)$. 
Video pembelajaran merupakan media pembelajaran audio visual yang menyajikan materi pelajaran. Video pembelajaran digunakan untuk membantu siswa memahami materi pelajaran. Video pembelajaran menyajikan gambar dan audio yang memiliki unsur gerak (4). Sehingga, video pembelajaran dapat dijadikan sumber belajar yang menarik bagi siswa. Selain itu, dengan video pembelajaran, siswa menjadi termotivasi untuk belajar.

Sparkol Videoscribe merupakan aplikasi yang digunakan untuk membuat video animasi. Sparkol Videoscribe dapat menggabungkan gambar, suara, dan desain yang menarik $(2,3,5,6,7,8)$. Sehingga, Sparkol Videoscribe dapat menyajikan materi pelajaran dalam bentuk yang menarik. Oleh karena itu, pembelajaran menjadi menyenangkan dan tidak monoton. Siswa pun menjadi berminat dan termotivasi untuk belajar.

Sumber belajar merupakan segala sesuatu yang dapat digunakan untuk memfasilitasi proses belajar. Sumber belajar disajikan dalam berbagai bentuk media cetak, media non cetak, elektronik, software, maupun hardware $(6,16)$. Sumber belajar merupakan komponen yang penting dalam mencapai tujuan pembelajaran.

Inovasi pembelajaran dilakukan untuk meningkatkan proses pembelajaran (20). Inovasi pembelajaran dapat dilakukan pada media pembelajaran (18). Media pembelajaran digunakan sebagai sumber belajar bagi siswa (9). Media pembelajaran adalah sesuatu yang digunakan untuk menyampaikan pesan atau materi pelajaran. Media pembelajaran mampu merangsang rasa ingin tahu, pikiran, perasaan, dan perhatian siswa untuk belajar $(6,10,11)$. Sehingga, dengan media pembelajaran akan terjadi proses pembelajaran dan tujuan pembelajaran tercapai (19). Oleh karena itu, guru harus mampu memilih media pembelajaran yang tepat agar membuat siswa termotivasi untuk belajar

Youtube, Instagram, WhatsApp, dan Facebook

Youtube merupakan aplikasi untuk meng-upload dan menonton video di media sosial (12). Instagram merupakan aplikasi yang dapat mengambil foto dan video yang disertai dengan filter serta membagikannya kepada orang lain di jejaring sosial (13). WhatsApp merupakan suatu aplikasi yang memungkinkan penggunanya untuk berbagi video, foto, dan pesan baik teks maupun suara serta melakukan panggilan berupa suara maupun video (14). Kemudian, Facebook adalah media sosial yang memungkinkan pengguna untuk saling berinteraksi (bertukar pesan) serta mengunggah foto, video, dan status/komentar (15).

Jorong Kampung Padang Paraman Dareh terletak di Nagari Aia Manggih, Kecamatan Lubuk Sikaping, Kabupaten Pasaman, Provinsi Sumatera Barat. 


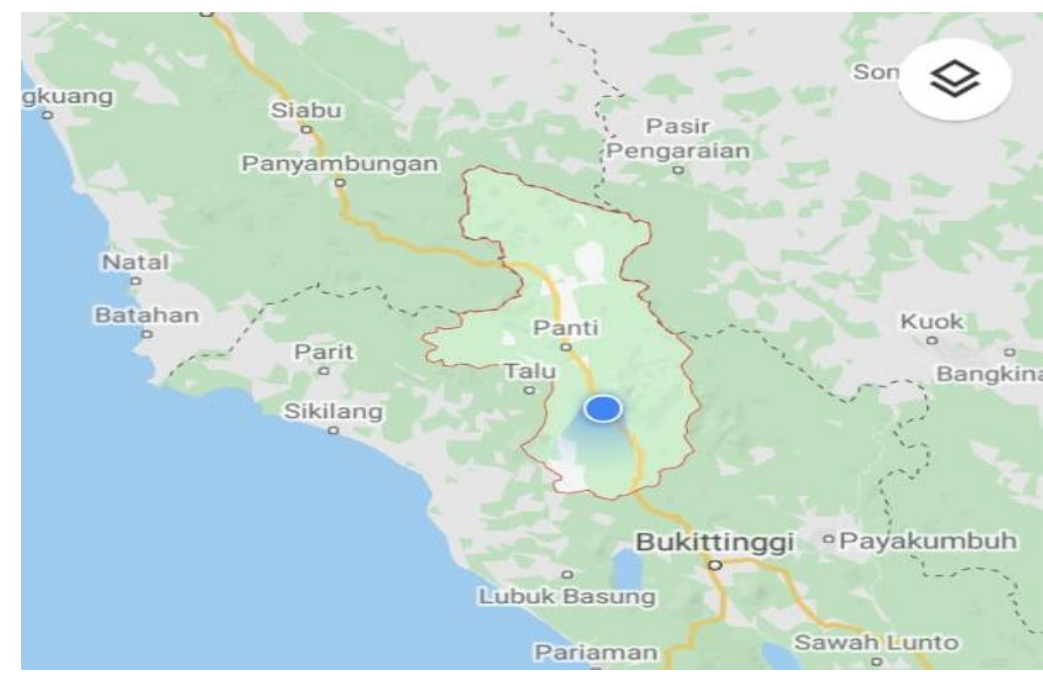

\section{Pelaksanaan}

\section{Gambar 4. Jorong Kampung Padang Paraman Dareh}

\section{Tahap Persiapan}

Pembuatan video dilakukan selama 3 hari mulai tanggal 27-29 Juni 2020. Video yang dibuat terdiri dari 3 video yang memuat tentang, yaitu (1) pengertian matriks dan jenis-jenis matriks; (2) kesamaan dan operasi pada matriks; dan (3) transpose, determinan, dan invers matriks. Aplikasi yang digunakan adalah Sparkol Videoscribe.

Kemudian, pada tahapan ini juga meminta izin KKN kepada Wali Nagari Aia Manggih pada tanggal 29 Juni 2020. Namun, yang bisa ditemui waktu itu adalah Sekretaris Nagari, Febria Nelsya. Setelah itu, pada tahapan ini dilakukan survei terhadap kondisi di lapangan seperti kondisi siswa saat pembelajaran online di tengah pandemi Covid-19. Survei ini dilakukan melalui google form yang dikirim melalui kontak WhatsApp. Survei melibatkan 20 orang siswa SMA/SMK kelas XI. Survei dilakukan pada tanggal 1-2 Juli 2020.
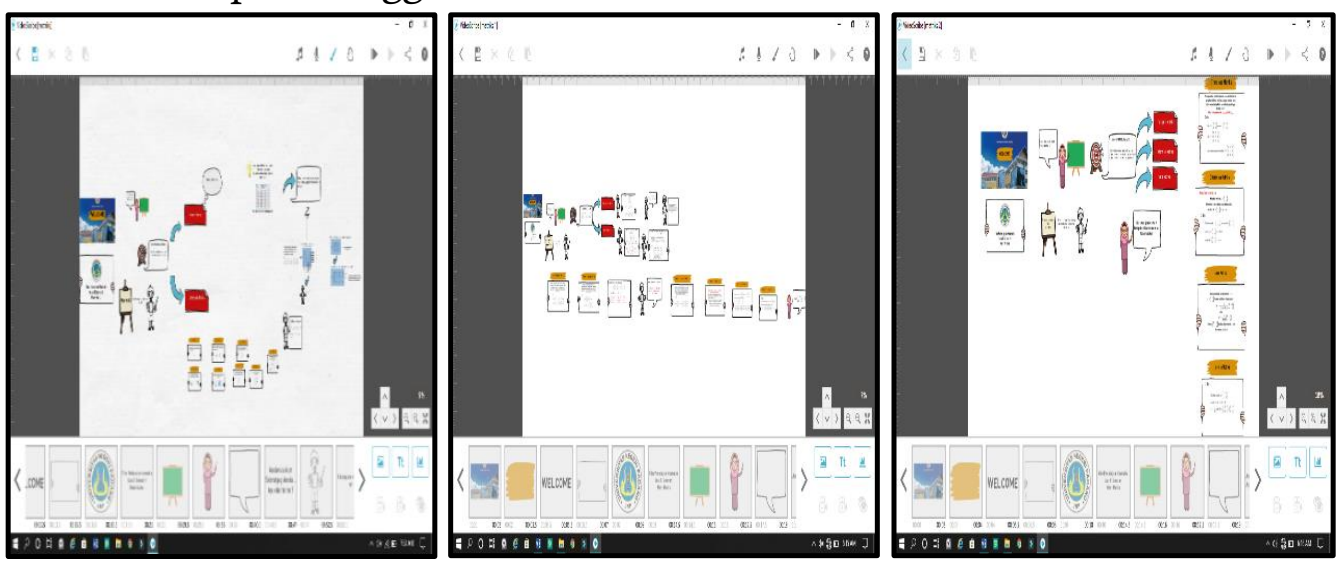

(a) 


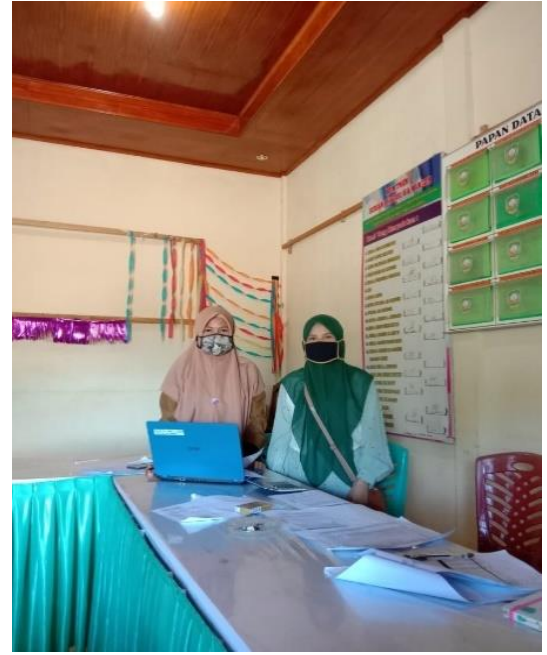

(b)

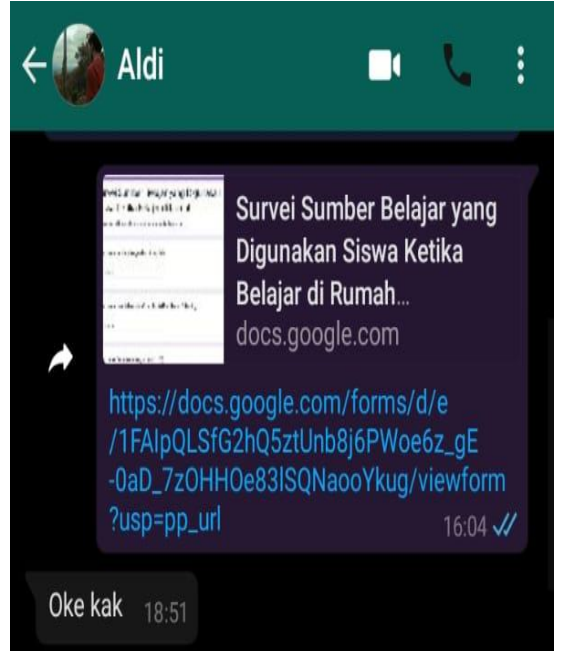

(c)

Gambar 5.(a) Pembuatan Video Pembelajaran Pertama, Kedua, dan Ketiga (b) Perizinan di Kantor Wali Nagari Aia Manggih

(c) Survei yang Dilakukan Kepada Salah Satu Siswa Melalui WhatsApp

\section{Tahap Pelaksanaan}

Video pembelajaran yang telah dibuat dipublikasikan dengan metode SYIFW. Video pembelajaran dipublikasikan melalui jejaring sosial Youtube, Instagram, Facebook, dan WhatsApp.

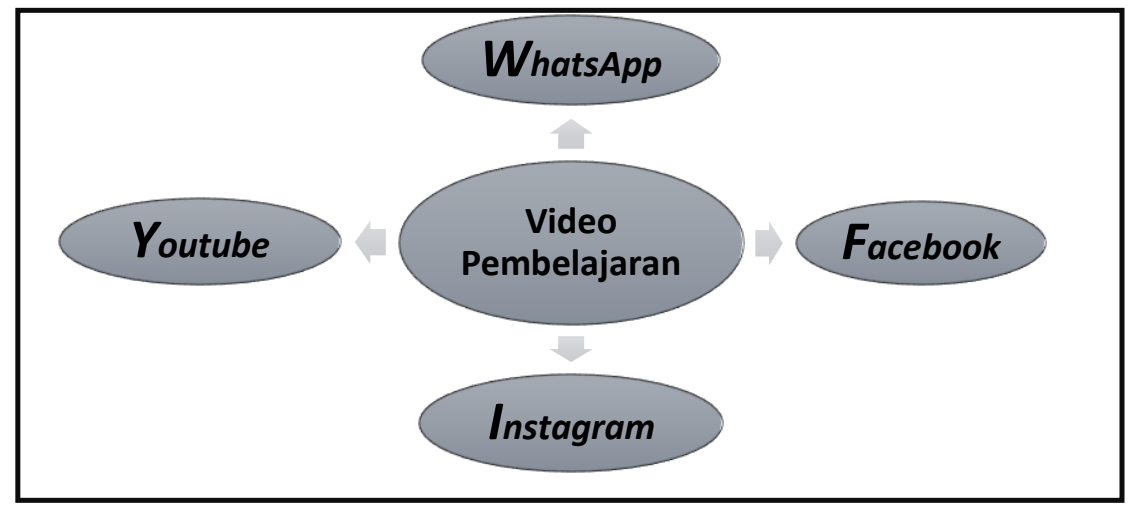

Gambar 6. Metode SYIFW (Sharing to Youtube, Instagram, Facebook, dan WhatsApp)

Video pembelajaran yang telah dibuat, di-upload ke Youtube pada hari Selasa, 30 Juni 2020. Video pembelajaran mendapat like dan comment yang baik. Bahkan, 
like dan comment yang didapat lebih banyak dari video yang di-upload sebelumnya. Jadi, adanya peningkatan setelah meng-upload video pembelajaran ini.

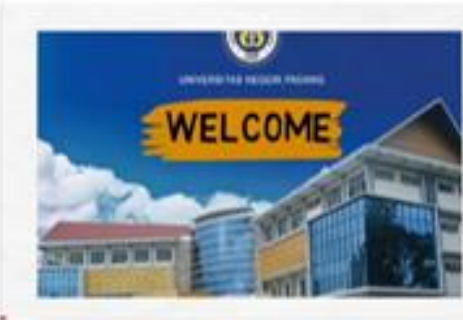

Video Pembelajaran | Pengertian dan Jenis Matriks

51 viren 5 deys apo

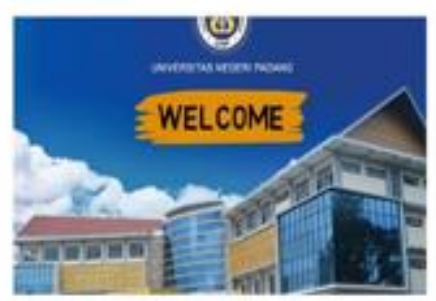

* Video Pembelajaran | Kesamaan dan Operasi Matriks

If vims 5 dans ago

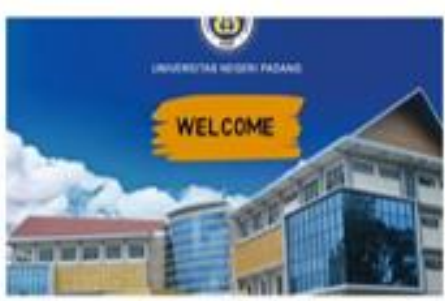

Video Pembelajaran I Traspose, Determinan, dan Inwers Matriks

4 viens ' 5 daps aps
16 \%
$A$
thare Oownibad Save
16
Ahare Downitos $\underset{\text { Sree }}{\mathbf{4}}$

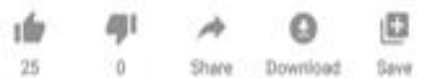
Lialy Sarti
SUBSCRIBE
Lialy Sarti
SUBSCRIBE
(7) Lialy Sarti
SU8SCRIBE

\section{Gambar 7. Postingan di Youtube}

Selain itu, video pembelajaran tersebut juga di-upload di Facebook pada tanggal 3 Juli 2020. Begitu juga di Instagram, di-upload pada tanggal 4 Juli 2020. Kedua postingan ini mendapat like yang lebih banyak dari Youtube. Bahkan, ada yang terinspirasi untuk membuat video pembelajaran dengan menggunakan aplikasi Sparkol Videoscribe.

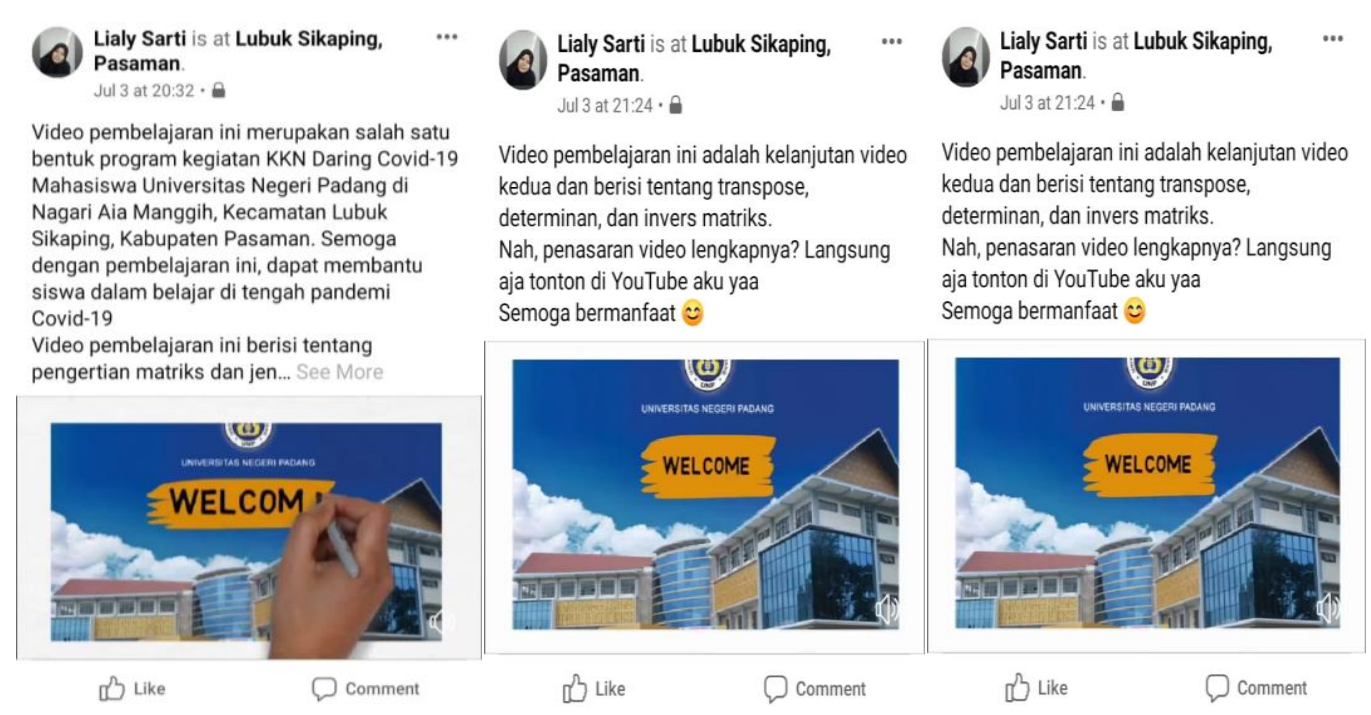

(a) 


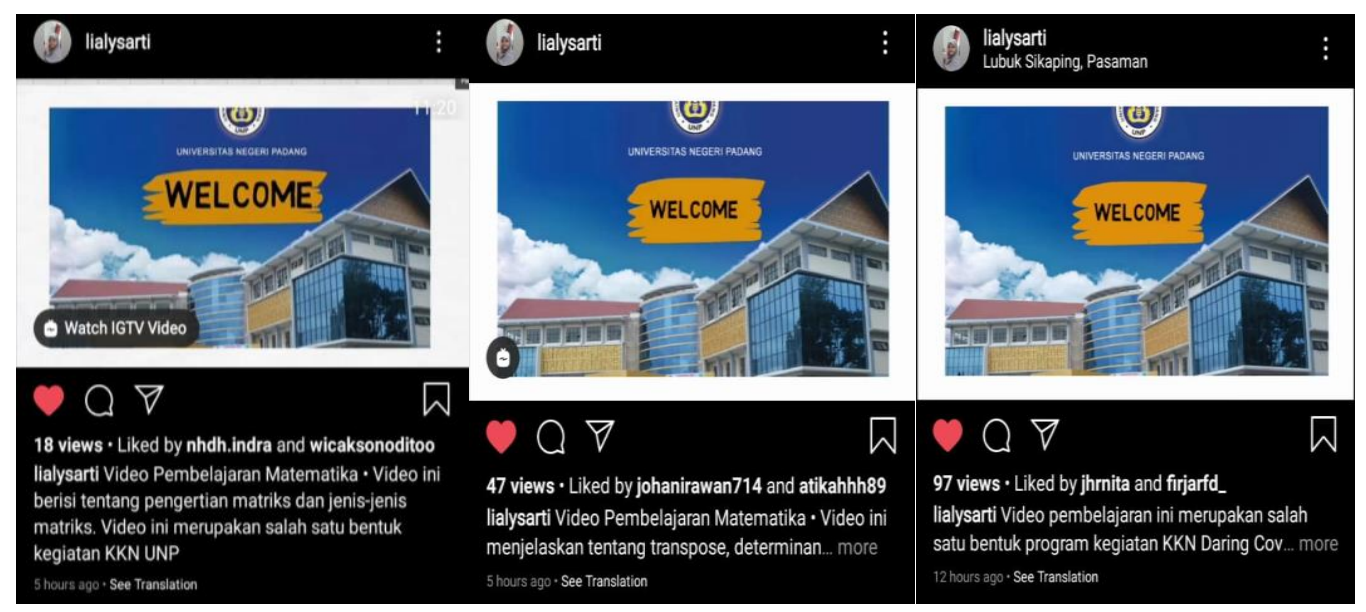

(b)

\section{Gambar 8. (a) Postingan di Facebook (b) Postingan di Instagram}

Kemudian, video tersebut juga dikirim kepada 20 orang siswa SMA/SMK kelas XI melalui grup WhatsApp. Dua puluh siswa tersebut diminta untuk menonton video pembelajaran yang telah dikirim. Namun, banyak dari siswa tersebut yang tidak online karena tidak ada kuota internet. Sehingga, video pembelajaran diberikan secara langsung dengan mendatangi rumah siswa bagi yang tidak bisa dihubungi. Dengan begitu, siswa dapat menonton video pembelajaran serta dapat memberikan tanggapannya terhadap video tersebut.

Berikut data 20 orang siswa SMA/SMK kelas XI yang dilibatkan.

\begin{tabular}{|l|l|c|l|c|}
\hline No. & \multicolumn{1}{|c|}{ NAMA } & KELAS & \multicolumn{1}{c|}{ SMA/SMK } & No. HP \\
\hline 1. & Aqsal Djilham Putra & XI & SMAN 1 Lubuk Sikaping & 082387709376 \\
\hline 2. & Fadillah Abdi Rama & XI & SMAN 2 Lubuk Sikaping & 082171186599 \\
\hline 3. & Aldi Kurniawan & XI & SMAN 3 Sumatera Barat & 081270150809 \\
\hline 4. & Putri Abdina Sari & XI & SMAN 1 Lubuk Sikaping & 082343859953 \\
\hline 5. & Intan Permata Sari & XI & SMAN 2 Lubuk Sikaping & 083193304973 \\
\hline 6. & Hermanto & XI & SMKN 1 Lubuk SIkaping & 082385843943 \\
\hline 7. & Fitrila Hanifah & XI & SMAN 1 Lubuk Sikaping & 082384778359 \\
\hline 8. & Dio Ardila Putra & XI & SMKN 1 Lubuk Sikaping & 085274845910 \\
\hline 9. & Fiona Rantika & XI & SMAN 1 Lubuk Sikaping & 082358777485 \\
\hline 10. & Liza Artita & XI & SMKN 1 Lubuk Sikaping & 085363640812 \\
\hline 11. & Dita Dianti Ahda & XI & SMAN 1 Lubuk Sikaping & 085264755095 \\
\hline 12. & Zira Tunisa & XI & SMKN 1 Lubuk Sikaping & 082387446380 \\
\hline 13. & Sisri & XI & SMKN 1 Lubuk Sikaping & 082387048562 \\
\hline 14. & Nesa Rahmita Sari & XI & SMKN 1 Lubuk Sikaping & 082391688775 \\
\hline 15. & Ahmad Fauzi & XI & SMKN 1 Lubuk Sikaping & 081378155183 \\
\hline 16. & Jelita & XI & SMKN 1 Lubuk Sikaping & 081363606715 \\
\hline
\end{tabular}




\begin{tabular}{|l|l|c|l|l|}
\hline 17. & Bima Septiawan & XI & SMAN 1 Lubuk Sikaping & 082385582738 \\
\hline 18. & Vicky Mardaes & XI & SMAN 2 Lubuk Sikaping & 085264748560 \\
\hline 19. & Fitrah Ini & XI & SMKN 1 Lubuk Sikaping & 085374566508 \\
\hline 20. & Wilda Nuraini & XI & SMAN 2 Lubuk Sikaping & 085363770816 \\
\hline
\end{tabular}

Tabel 1. Data Siswa Kelas XI SMA/SMK di Jorong Kampung Padang Paraman Dareh

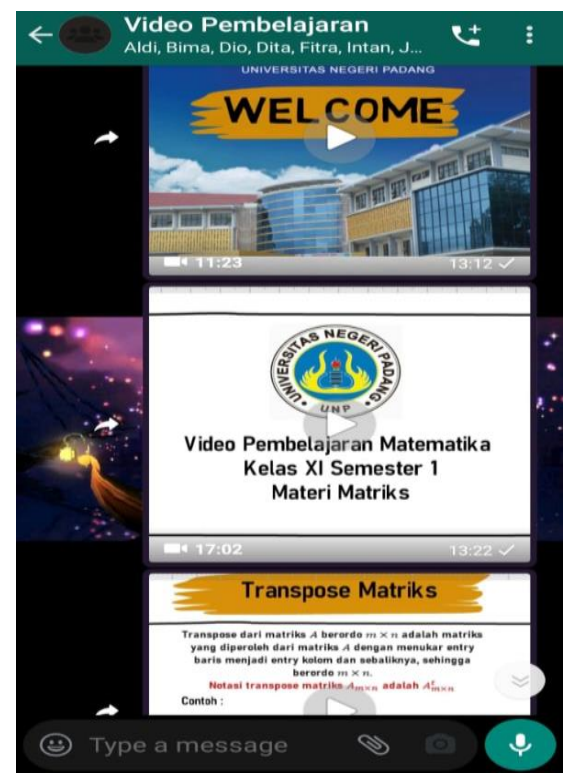

Gambar 9. Sharing di Grup WhatsApp

\section{Tahap Evaluasi}

Pada tahapan ini, evaluasi dilakukan dengan memberikan angket secara online (melalui google form). Angket berisi tentang tanggapan siswa terhadap video pembelajaran, apakah dapat membantu siswa atau tidak. Angket ini diberikan melalui grup WhatsApp yang terdiri dari 20 orang siswa tersebut. Sama halnya dengan video pembelajaran, pemberian angket juga mengalami kendala. Siswa juga jarang online karena tidak ada kuota internet. Sehingga, untuk pengisian angket ini juga dilakukan dengan mendatangi rumah siswa bagi yang tidak bisa dihubungi. Angket diberikan pada 4 Juli 2020. Pengisian angket dilakukan sampai 6 Juli 2020. Selain itu, wawancara dengan guru juga dilakukan pada 4 Juli 2020. Guru dimintai tanggapan tentang kendala/kesulitan yang dihadapinya di tengah pembelajaran online. Selain itu, juga diminta tanggapan tentang kepahaman siswa terhadap pelajaran selama pembelajaran online. 


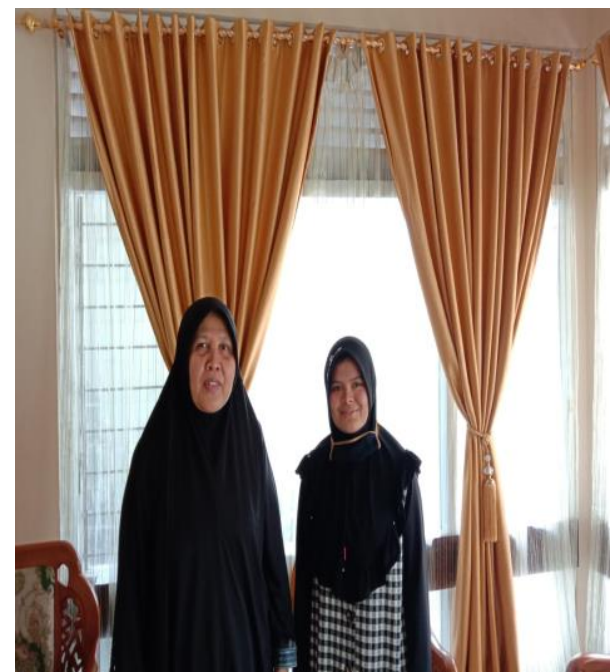

(a)

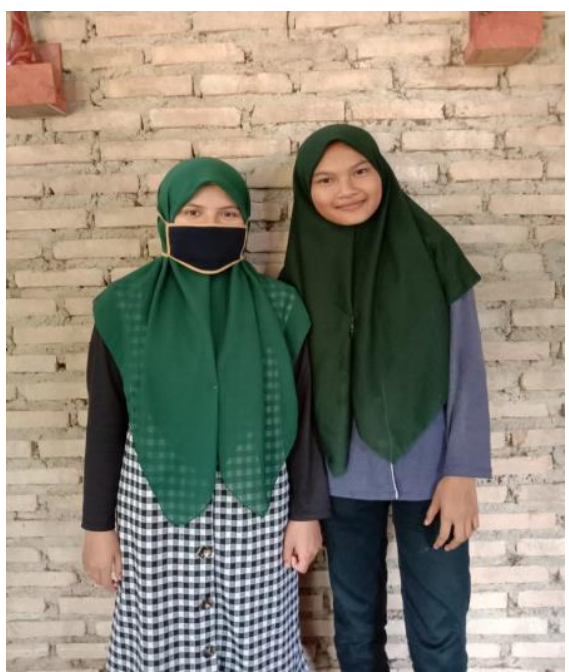

(b)

Gambar. 10 (a) Wawancara dengan Guru (b) Pemberian Angket Kepada Siswa

\section{Hasil Implementasi dan Respon}

Untuk mendapatkan respon 20 orang siswa terhadap video pembelajaran, maka dilakukan survei dengan memberikan angket (google form) melalui WhatsApp. Angket ini bertujuan untuk melihat respon siswa tentang belajar dengan menggunakan video pembelajaran. Dengan begitu, dapat diketahui apakah video pembelajaran dapat membantu siswa dalam belajar atau tidak. Berikut angket yang diberikan kepada siswa.
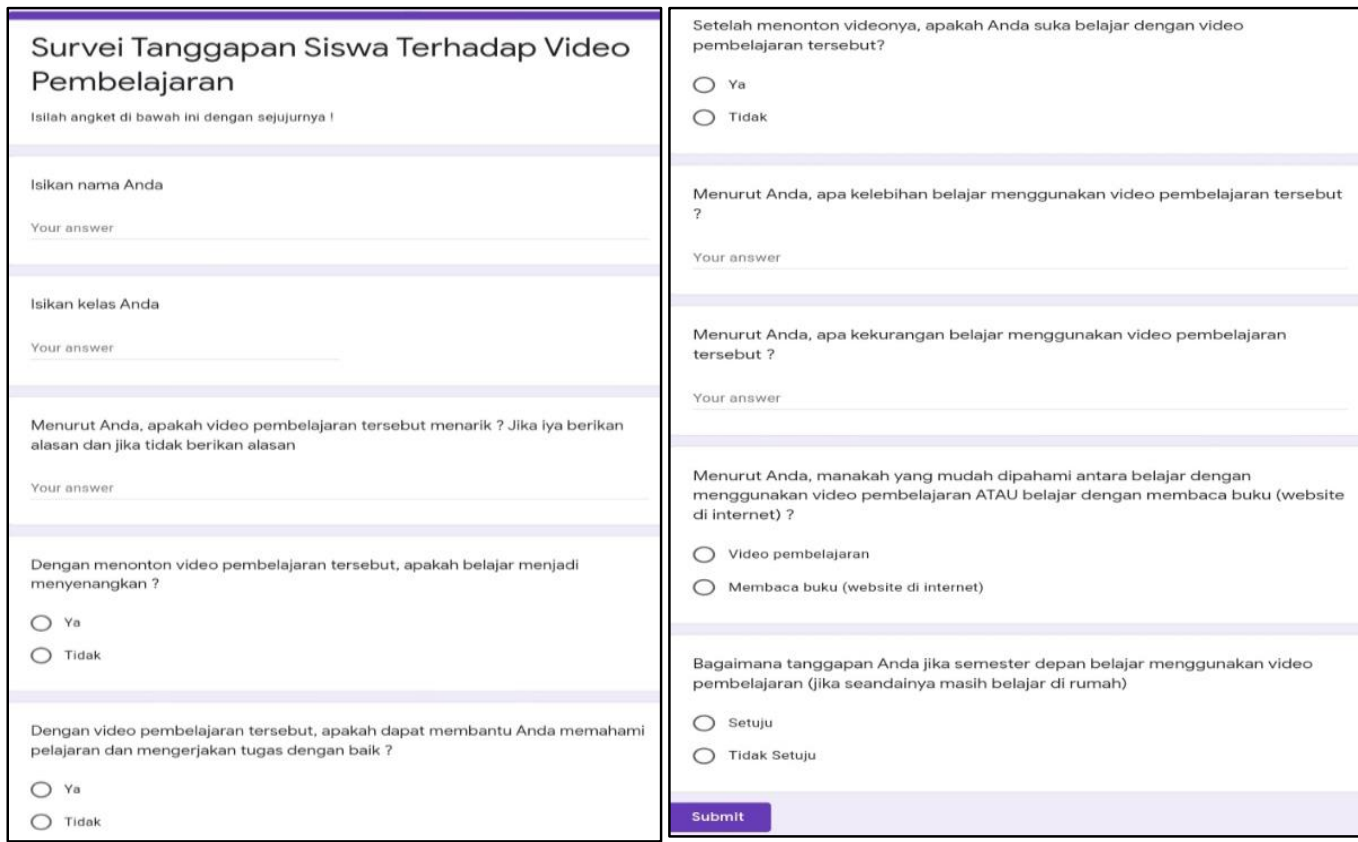

Gambar 11. Angket Evaluasi 
Berdasarkan hasil survei yang telah dilakukan, siswa lebih mampu memahami pelajaran dengan menggunakan video pembelajaran. Dari 20 orang siswa tersebut, $85 \%$ diantaranya dapat memahami pelajaran dan mengerjakan tugas dengan baik menggunakan video pembelajaran. Jadi, dapat dilihat peningkatan kepahaman siswa terhadap pelajaran sebesar $30 \%$.

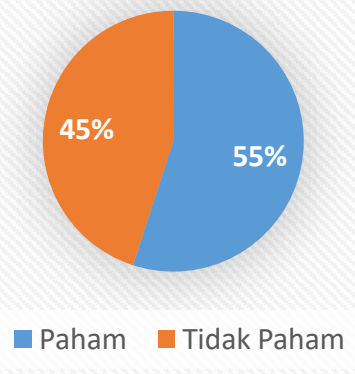

(a)

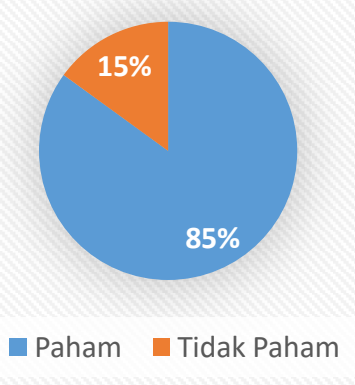

(b)

Gambar 12. (a) Persentase Tingkat Kepahaman Siswa Terhadap Pelajaran Sebelum Diberikan Video Pembelajaran (b) Persentase Tingkat Kepahaman Siswa Terhadap Pelajaran Sesudah Diberikan Video Pembelajaran

Selain itu, tanggapan siswa terhadap video pembelajaran juga baik. Video pembelajaran membuat siswa besemangat untuk belajar. Belajar juga menjadi menyenangkan karena ada animasi atau gambar yang menarik. Dengan video pembelajaran, siswa lebih mudah memahami pelajaran. Hal ini disebabkan karena adanya penjelasan yang jelas dan rinci serta disertai contoh dari guru. Dengan video pembelajaran, siswa juga dapat melihat (membaca) sekaligus mendengarkan penjelasan dari guru. Sehingga dapat dikatakan, kedua organ yaitu telinga dan mata difungsikan untuk menonton video. Itulah yang membuat siswa lebih mudah memahami pelajaran. Selain itu, siswa juga mudah mengingat pelajaran. Video pembelajaran dapat diulang-ulang. Sehingga, jika ada yang tidak dipahami video dapat diulang kembali. Jadi dapat disimpulkan bahwa, video pembelajaran dapat membantu siswa dalam belajar di tengah pandemi Covid-19.

Video pembelajaran dapat dijadikan sumber belajar bagi siswa. Berdasarkan hasil survei tersebut, 95\% diantaranya atau 19 dari 20 orang siswa suka belajar dengan menggunakan video pembelajaran. Bahkan, siswa tersebut lebih suka belajar dengan menonton video pembelajaran dibanding membaca buku (website di internet). Hal ini disebabkan, membaca buku membuat siswa harus memahami sendiri. Bahkan, setelah membaca buku siswa cenderung tidak bisa memahami pelajaran. Hal ini menunjukkan bahwa siswa juga membutuhkan penjelasan dari guru.

Selain itu, di zaman sekarang segala kehidupan tidak lepas dari smartphone. Apalagi remaja yang selalu menggunakan smartphone-nya baik untuk bermain game, mengakses media sosial, mencari informasi, dan sebagainya. Momen ini 
bisa dijadikan kesempatan untuk memanfaatkan video pembelajaran di tengah pembelajaran online. Video pembelajaran dapat ditonton melalui smartphone siswa. Sehingga, siswa bisa menonton video tersebut sambil tetap menggunakan smartphone-nya. Bahkan, menonton video bisa dilakukan di sela aktivitas lainnya dengan menggunakan smartphone-nya. Selain itu, video pembelajaran memiliki animasi, suara, dan gambar yang menarik. Sehingga, juga membuat siswa tertarik untuk belajar. Pembelajaran pun juga menjadi menyenangkan dengan video pembelajaran.

Begitu juga dengan guru yang memberikan respon positif terhadap video pembelajaran. Berdasarkan wawancara dengan salah satu guru matematika, guru tersebut menjadi terinspirasi untuk menggunakan video dalam pembelajaran. Menurut guru, video pembelajaran memberikan solusi untuk pembelajaran online di tengah pandemi Covid-19. Dengan video pembelajaran, guru bisa memberikan penjelasan yang jelas dan rinci tentang pelajaran. Sehingga, siswa tidak bingung dan mampu memahami pelajaran dengan baik. Selain itu, siswa juga berminat dan termotivasi untuk belajar. Sehingga, dengan video pembelajaran dapat mengusir kecemasan guru akan siswa yang tidak paham dengan pelajaran. Walaupun tidak seperti tatap muka yang adanya interaksi dua arah, dimana siswa juga dapat bertanya kepada gurunya jika kurang paham. Akan tetapi, dengan video pembelajaran setidaknya siswa sudah mendengar dan melihat penjelasan dari guru secara langsung. Jadi dapat disimpulkan bahwa, dengan video pembelajaran guru bisa yakin dapat membantu siswa memahami pelajaran.

\section{Hal yang Menunjang}

Video pembelajaran dikirim ke siswa melalui WhatsApp. Kemudian, siswa bisa menonton video tersebut di smartphone mereka. Pada saat melakukan survei, dapat dilihat bahwa setiap siswa memiliki smartphone. Sehingga, siswa dapat mengunggah dan menonton video tersebut melalui smartphone. Jadi, proses sosialisasi terhadap siswa dapat dilakukan dengan lancar. Selain itu, juga didukung dengan jaringan yang baik. Sehingga, komunikasi dengan siswa juga baik serta unggahan video juga dapat dilakukan dengan cepat. Selain itu, respon positif yang diberikan guru terhadap video pembelajaran, juga membuat sosialisasi berjalan lancar. Guru juga antusias serta tertarik untuk menggunakan video pembelajaran sebagai media pembelajaran.

\section{Hal yang Menghambat}

Walaupun setiap siswa memiliki smartphone, namun banyak sekali siswa yang tidak memiliki kuota internet. Bahkan, hanya 25\% siswa yang memiliki kuota internet. Selain itu, walaupun siswa tersebut memiliki kuota internet, namun jarang siswa dalam keadaan online ketika dihubungi. Sehingga, harus menelpon 
siswa agar membaca pesan di WhatsApp. Angket (google form) dan video pembelajaran dikirim melalui WhatsApp. Jika siswa tidak online, maka akan kesulitan untuk berkomunikasi dengan siswa atau mendapatkan respon dari siswa. Selain itu, siswa juga kurang antusias untuk memberikan tanggapannya. Bahkan, siswa acuh untuk diminta mengisi angket, apalagi diminta untuk menonton video pembelajaran. Bahkan, ketika ditanyai melalui WhatsApp, siswa juga jarang mau membaca pesan. Sehingga, dengan kondisi-kondisi tersebut, maka harus mendatangi rumah masing-masing siswa untuk meminta tanggapannya. Itulah hambatan yang dihadapi dari siswa. Selain itu, hambatan dari guru juga ada. Walaupun respon guru baik untuk video pembelajaran, namun guru masih belum bisa menggunakan teknologi dengan baik. Selain itu, menurut guru membuat video pembelajaran merupakan hal yang sulit baginya. Mengingat video tesebut juga akan membutuhkan waktu yang cukup lama. Sehingga, membuat guru menjadi repot untuk hanya menyiapkan satu video saja. Ditambah juga faktor usia guru yang membuatnya berpikir dua kali untuk membuat video pembelajaran. Jadi, itulah kesulitan guru dalam membuat video pembelajaran berbasis Sparkol Videoscribe.

\section{Planning Replikasi}

Video pembelajaran berbasis Sparkol Videoscribe merupakan media pembelajaran yang dapat dijadikan sumber belajar. Kemudian, tentu ada hal yang dibutuhkan dan dipersiapkan agar dapat menciptakan sebuah video pembelajaran berbasis Sparkol Videoscribe. Untuk membuat video pembelajaran tersebut, maka dapat menggunakan aplikasi yang di-instal di PC/laptop. Aplikasi tersebut adalah aplikasi Sparkol Videoscribe. Setelah itu, menentukan materi pelajaran sesuai Kompetensi Dasar (KD) pada kurikulum. Tentunya guru juga sudah menyesuaikan kelas dan semester yang diajar. Kemudian, dilanjutkan dengan membuat video. Dalam pembuatan video, perlu diperhatikan dan dipelajari menu dan tools yang ada pada aplikasi. Setelah selesai membuat video, maka dilakukan proses pengeditan terhadap tulisan, waktu animasinya, dan sebagainya. Setelah itu, merekam (record) suara dari penjelasan guru terhadap materi tersebut. Selain itu, juga bisa ditambahkan musik supaya lebih menarik dengan syarat volumenya kecil. Tujuannya, supaya suara dari guru tetap terdengar walaupun ada musik. Kemudian, yang terakhir adalah export video. Proses export ini membutuhkan waktu yang cukup lama. Nah, itulah yang harus dipersiapkan serta langkahlangkah dalam membuat video pembelajaran berbasis Sparkol Videoscribe.

\section{Penutup}

Berdasarkan pembahasan di atas, maka dapat disimpulkan bahwa video pembelajaran berbasis Sparkol Videoscribe dapat membantu siswa dan guru di 
Jorong Kampung Padang Paraman Dareh di tengah pembelajan online. Video pembelajaran dapat dijadikan sebagai sumber belajar bagi siswa dan sebagai inovasi pembelajaran bagi guru. Video pembelajaran tersebut membuat siswa bersemangat untuk belajar. Selain itu, belajar pun menjadi menyenangkan karena adanya animasi atau gambar yang menarik. Siswa juga lebih mudah memahami pelajaran dengan menggunakan video pembelajaran tersebut. Hal ini disebabkan adanya penjelasan yang jelas dan rinci dari guru. Selain itu, video pembelajaran juga membantu guru dalam menyampaikan materi pelajaran. Sehingga, video pembelajaran tersebut dapat dijadikan media dalam belajar online di tengah pandemi Covid-19. Dengan begitu, kesulitan siswa dan guru di tengah pembelajaran online (daring) dapat teratasi.

\section{Ucapan Terima Kasih}

Segala puji dan syukur kepada Allah SWT yang telah melimpahkan rahmat dan karunia-Nya, sehingga penulis bisa menyelesaikan laporan KKN ini. Pada kesempatan ini, penulis juga menyampaikan rasa terima kasih kepada :

a. Dr. Rahadian Zainul, S.Pd., M.Si., selaku Dosen Pembimbing Lapangan (DPL) KKN yang telah memberikan bimbingan dalam melaksanakan KKN serta menyelesaikan laporan KKN ini.

b. Arif Afandi, S.STP, selaku Wali Nagari Aia Manggih

c. Febria Nelsya, selaku Sekretaris Nagari Aia Manggih

d. Nelwitis, S.Pd., selaku guru matematika kelas XI SMA Negeri 1 Lubuk Sikaping

e. Israhayu, S.E., selaku Kepala Jorong Kampung Padang Paraman Dareh

f. Siswa kelas XI SMA/SMK di Jorong Kampung Padang Paraman Dareh

\section{Referensi}

(1) Syamsiah T. Perbedaan Kemampuan Sosialisasi antara Siswa yang Mengikuti dan yang Tidak Mengikuti Kegiatan Ekstrakurikuler. Ilmu Pendidikan: Jurnal Kajian Teori dan Praktik Kependidikan. 2009 Feb 12;28(2).

(2) Dewi CS, Suprapto PK, Badriah L. Peranan media sparkol videoscribe terhadap hasil belajar kognitif siswa lintas minat biologi. JPBIO (Jurnal Pendidikan Biologi). 2019 Nov 29;4(2):93-100.

(3) Edison E. Peningkatan Hasil Belajar Mahasiswa Pgmi Pada Mata Kuliah Matematika SD/MI Melalui Penggunaan Media Pembelajaran Berbasis Sparkol Videoscribe Di IAI Muhammadiyah Bima. Jurnal Basicedu. 2017 Oct 5;1(2):5965.

(4) Gusliati P, Eliza D, Hartati S. Analisis Video Pembelajaran Share Book Reading Menggunakan Cerita Rakyat Sabai Nan Aluih pada Anak Usia Dini. Jurnal Obsesi: Jurnal Pendidikan Anak Usia Dini. 2019 May 27;3(2):320-6. 
(5) Hasan AA, Baroroh U. Pengembangan Media Pembelajaran Bahasa Arab Melalui Aplikasi Videoscribe Dalam Meningkatkan Motivasi Belajar Siswa. J لـ ساذ ـ نـ (LISANUNA): Jurnal Ilmu Bahasa Arab dan Pembelajarannya. 2020 Apr 11;9(2):140-55.

(6) Pamungkas AS, Ihsanudin I, Novaliyosi N, Yandari IA. Video pembelajaran berbasis sparkol videoscribe: Inovasi pada perkuliahan sejarah matematika. Prima: Jurnal Pendidikan Matematika. 2018 Jul 28;2(2):127-35.

(7) Pratiwi ED, Latifah S, Mustari M. Pengembangan Media Pembelajaran Fisika Menggunakan Sparkol Videoscribe. Indonesian Journal of Science and Mathematics Education. 2019 Jun 23;2(3):303-9.

(8) Rahmatika DF, Ratnasari N. Media Pembelajaran Matematika Bilingual Berbasis Sparkol Videoscribe. Desimal: Jurnal Matematika. 2018 Sep 30;1(3):385-93.

(9) Wahyudi S, Handayani AN, Herwanto HW. Pengembangan Sumber Belajar Matakuliah Sistem Cerdas Kompetensi Jaringan Syaraf Tiruan. SENTIA 2017. 2017 Oct 19;9.

(10) Purwanto Y, Riadi I. Implementasi Multimedia Sebagai Media Pembelajaran (Studi Kasus: Materi Subnetting Pada IPv4) (Doctoral dissertation, Universitas Ahmad Dahlan).

(11) Satria W, Handayaningsih S. Pembuatan Media Pembelajaran Untuk Proses Konversi Pada Finate Automata Berbasis Multimedia (Doctoral dissertation, Universitas Ahmad Dahlan).

(12) Imam C. TA: Perancangan Media Promosi Video Youtube Koleksi Sanggar Gubug Wayang Mojokerto Berbasis Budaya Sebagai Upaya Meningkatkan Brand Awareness (Doctoral dissertation, Institut Bisnis dan Informatika Stikom Surabaya).

(13) Utami RP, Probosari RM, Fatmawati UM. Pengaruh Model Pembelajaran Project Based Learning Berbantu Instagram Terhadap Kemampuan Berpikir Kreatif Siswa Kelas X SMA Negeri 8 Surakarta. Bio-Pedagogi. 2015;4(1):47-52.

(14) Yudha GD. Pemanfaatan Aplikasi Facebook Dalam Membangun E-Learning Dengan Metode Asynchronous Collaborative Learning di Politeknik Cilacap. Esensi: Jurnal Bisnis dan Manajemen. 2014 Dec 3;4(3).

(15) Zakirman Z, Rahayu C. Popularitas WhatsApp sebagai media komunikasi dan berbagi informasi akademik mahasiswa. Shaut Al-Maktabah: Jurnal Perpustakaan, Arsip dan Dokumentasi. 2018 Oct 17;10(1):27-38.

(16) Rifai A, Sulton S, Sulthoni S. Pengembangan Media Mobile Learning Sebagai Pendukung Sumber Belajar Biologi Siswa SMA. Jurnal Kajian Teknologi Pendidikan. 2020 Jan 22;3(1):10-7.

(17) Murtani A. Sosialisasi Gerakan Menabung. Sindimas. 2019 Jul 29;1(1):279-83. 
(18) Sari CK, Muslihatun A, Cahyaningtyas L, Khaimmudin RN, Fijatullah RN, Nisa EU. Pemanfaatan permainan tradisional untuk media pembelajaran: Congklak bilangan sebagai inovasi pembelajaran matematika sekolah dasar. Transformasi: Jurnal Pengabdian Masyarakat. 2019 Jun 30;15(1):14-22.

(19) Situmorang M. Pengembangan buku ajar kimia Sma melalui inovasi pembelajaran dan integrasi pendidikan karakter untuk meningkatkan hasil belajar siswa. Prosiding SEMIRATA 2013. 2014 Sep 13;1(1).

(20) Kristiawan M, Rahmat N. Peningkatan Profesionalisme Guru Melalui Inovasi Pembelajaran. Jurnal Iqra': Kajian Ilmu Pendidikan. 2018 Dec 15;3(2):373-90. 